\title{
Planning Green Space for Climate Change Adaptation and Mitigation: A Review of Green Space in the Central City of Beijing
}

\author{
Feng Li ${ }^{1,}$, , Paul Sutton ${ }^{2}$, Hamideh Nouri ${ }^{3}$ \\ ${ }^{1}$ Fujian Provincial Key Laboratory of Soil Environmental Health and Regulation, College of Resources and Environment, Fujian Agriculture \\ and Forestry University, Fuzhou, P. R. China \\ ${ }^{2}$ Department of Geography and the Environment, University of Denver, Denver, USA \\ ${ }^{3}$ Department of Water Engineering and Management, Faculty of Engineering Technology, University of Twente, Enschede, The Netherlands
}

\section{Email address:}

fenglee1972@163.com (Feng Li), paul.sutton@du.edu (P. Sutton), h.nouri@utwente.nl (H. Nouri)

${ }^{*}$ Corresponding author

\section{To cite this article:}

Feng Li, Paul Sutton, Hamideh Nouri. Planning Green Space for Climate Change Adaptation and Mitigation: A Review of Green Space in the Central City of Beijing. Urban and Regional Planning. Vol. 3, No. 2, 2018, pp. 55-63. doi: 10.11648/j.urp.20180302.13

Received: July 29, 2018; Accepted: August 28, 2018; Published: September 18, 2018

\begin{abstract}
The ongoing rapid urbanization and its socio-economic impacts on Chinese cities have engendered numerous environmental issues, food insecurity and significant stress on water resources besides accelerating some ecological degradation. Among these issues, urban-heat-island (UHI) and climate change in large cities had drawn much attention so that many researches on climate change adaptation and mitigation emerged in recent years. How to make the cities cool down and more liveable is more important than before for urban planning. Urban planners have been placing more stress on green space planning and the green environment of cities where dwellers crowd together. This paper is a review of green space in the Central City of Beijing under current situation and puts forward some advice on green space planning in responding to the climate change in the new era of China. Planning green space with the principal objective of "green-sponge-city" and the key concept of "low-carbon-city" is the primary adaptation and mitigation approach to climate change for urban planners and policymakers. No doubt, more attention and support from the government regarding strengthening green space systems in response to climate change will improve the liveability, resilience, and sustainability of cities in China.
\end{abstract}

Keywords: Green Space, Climate Change, Urban Heat Island, Low Carbon, Green Sponge

\section{Introduction}

In recent decades, climate change and rapid urbanization have become two major issues related to human welfare and development around the world [1]. Ample effort has been devoted to urban climatic studies in urban planning, which is challenging for both climatologists and urban planners [2]. Furthermore, with the accelerated of urbanization process and the effects of global warming, the urban-heat-island (UHI) effect becomes more and more problematic [3]. Urban green space is drawing more attention than before by virtue of its crucial role in improving the environmental quality and sustainability, providing a broad range of services and enriching social, ecological, and cultural values including landscape aesthetics, outdoor recreations, noise reduction and the most important of all, its cooling efficiency. The task ahead is to transform our existing cities to become more walkable, compact, sustainable and liveable. Nowadays it is essential to have a better understanding of the interplay between higher densities and the risk of the urban-heat-island (thermal load) where the air and surface temperatures are typically much higher than surrounding in large cities. The urban-heat-island had been recognized as a health-risk for city dwellers and centers of academic research topic in many nations all over the world [4]. With this regard, urban green space planning in $21^{\text {st }}$ century takes into consideration the social, ecological, and economic aspects of greening cities concerning sustainability of large cities [5]. It indicates that climate adaption and mitigation are presenting challenges to 
all urban areas and calling for improvement of green space planning in cities. "Plan Climate de Paris" (2004-2020) had stirred up the concern on urban planning especially green space planning as a tool for improving the city climate. Beijing-the capital city of China-which is one of the largest and oldest cities in the world is facing enormous population growth and rapid urbanization; This introduces complex environmental challenges to this megacity and could have adverse impacts on the quality of life for the Beijing residents. The Reform and Open Policy in China initiated in 1980s had brought a phase of rapid urbanization and expansion of Beijing which inevitably influenced the urban climate greatly and caused serious climatic problems such as the urban-heat-island phenomenon, weak wind conditions, and poor air quality [6]. In the meantime, rapid urbanization has led to the high density of concentrated population that caused the lack of green open space in Beijing. These changes present a challenge to protect Beijing's environment and ecology. In brief, the construction of ecological civilization issues an urgent appeal of better green space system of Beijing in New Era. Most important of all, a livable green space system will improve the quality of life for Beijing residents and enhance the image of Beijing as the capital city of China and its international standing all over the world. Basing on the research on climate change and green space planning in Fuzhou of China and Adelaide of South Australia [7], the present research is to conduct a concept of urban green space planning in the Central City of Beijing under current international situation and put forward a proposal on climate change and city development.

\section{The Climate Feature of Beijing and Location of the Central City of Beijing}

Beijing is located on the northern tip of the roughly triangular North China Plain (39_260N-41_040N, 115_250E$\left.117 \_300 \mathrm{E}\right)$, which covers an area of $16410 \mathrm{~km}^{2}$ and has a large population of 21 million. The maximum elevation of the urban region is around $200 \mathrm{~m}$, but the elevation of hilly areas varies from 200 to $2500 \mathrm{~m}$. The geography of Beijing is comprised of mountains, which account for $62 \%$ of its area and are located in the northwest, and lowlands called the "Beijing Plain" in the southeast where the elevation is below $100 \mathrm{~m}$ above sea level. It should be noted that Beijing is in East Asia which belongs to the warm temperate zone. The climate of this region is half moist continental monsoon with an average annual temperature of 11.8 Degree Celsius. The typical feature of the climate is four distinct seasons: dry and windy spring, hot and multi- rain summer, sunny and cool autumn, cold and dry winter [8]. Spring and autumn are short respectively lasting for two months and 6 weeks, but summer and winter last longer, respectively being about three months and more than five months. The Central City of Beijing locates in the "Beijing Plain" and consists of six districts (Haidian, Dongcheng, Xicheng, Chaoyang, Fengtai, Shijingshan) (figure 1) which have been looked on as the main city of the whole Beijing.

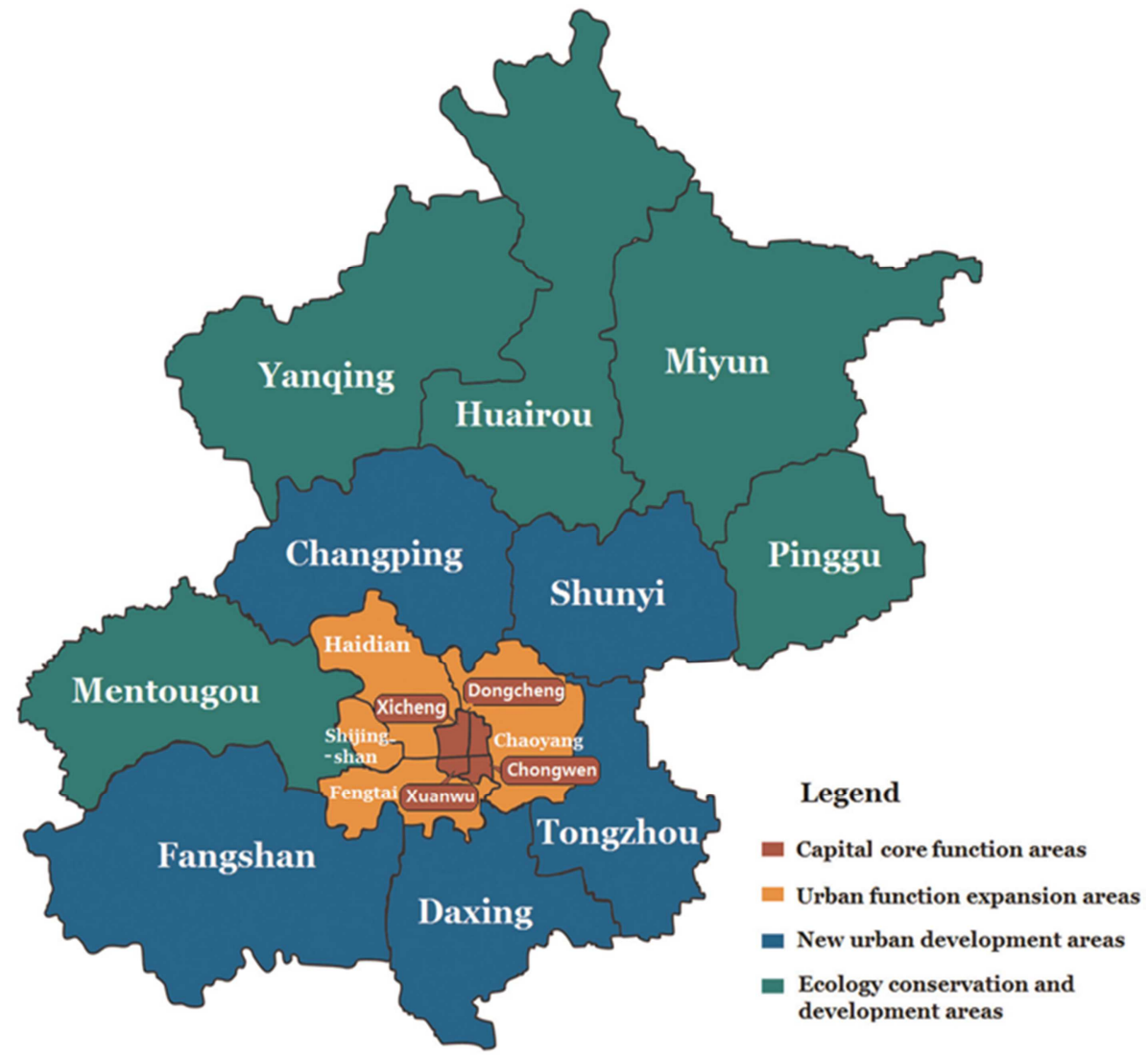

Figure 1. Scope of the Central City of Beijing. 


\section{Literature Review of Green Space Planning and Climate Change}

Currently there are numerous studies from various perspectives such including regional development, ecology and environmental protection emerged and green space planning of the megacity of Beijing. Some researchers assessed the ecological, economic and social characteristics of the evolutionary mechanisms and evolution processes for environmental protection \& sustainability of Beijing to enlighten the urban planners and policy makers. Tang Yan and Chen Kai studied the governance of urban green space planning for responding to climate change which is still a new research field. This study focused on the Central City of Beijing as a case study to explore how to regulate the urban thermal environment through the climate governance of green open spaces and stated that the thermal environment regulation effect of open green space is mainly represented by cooling efficiency. Therefore, the urban construction in Beijing needs to selected scientifically and reasonably in order to provide the appropriate pattern and size of urban green spaces with suitable plant configuration offering high cooling efficiency. This approach will facilitate appropriate landscaping structure to and consequently urban climate governance and landscaping effects [9]. Xiaodong He indicated that incorporating climatic information into green space planning practices of Beijing and its ecological setting is crucial to provide a healthy sustainable and comfortable living conditions for dwellers in Beijing [10]. Yazhou Zhang claimed that urban green shape influences the variety of urban land surface temperature and implemented this research in the Beijing metropolitan region [11]. There are several researchers that studied the role of green spaces adaptation or mitigation of climate change. For example, Haifeng Li suggested it is needed that natural green spaces with diverse vegetation configurations and complicated shapes which could connect the green spaces and form a green network of multifunctional greenways and green corridors. This setup can enhance the ecosystem services to both nature and people. Mahua Mukherjee and Kaoru Takara asserted that urban green space is a countermeasure of decreasing urban risk and attenuating urban-heat-island impact [12].

\section{Current Status of Green Space Planning of the Central City of Beijing from Responding to Climate Change Perspectives}

\subsection{Regulations in Beijing Green Space Planning (2004-2020) \& Beijing Urban Master Plan (2017-2035)}

According to Central Urban Regulatory Detailed Planning of Beijing (2004-2020), the planning area of the Central City is $1088 \mathrm{~km}^{2}$. The structure of green space in study area is a typical " 2 axis, 3 rings, 10 wedges, multiple parks" according to Beijing Green Space Planning (2004-2020) (Figure 2). These green wedges and green corridors form an integrated ecological network by connecting the urban center, forest parks, mountains and the outer regional space. By 2020, Beijing urban central area will be encircled by green hills and three green belts with the structure of Green Cross and ten green wedges. In addition, there will be some scattered parks of small and large size with the total green area of $132.6 \mathrm{~km}^{2}$. There are five types from the classification of parks named comprehensive parks, community parks, theme parks, belt-shaped parks, and country parks according to Beijing' green space system. And then, the green rate of the Central City of Beijing will increase up to $9.46 \%$. Consequently, the area and rate of green space per capita and park per capita will increase obviously (table 1). Nevertheless, green space per capita in the Central City of Beijing would be much less than that of some cities in South China such as the Central City of Fuzhou (table 2).

Table 1. The status of green spaces in the Central City of Beijing.

\begin{tabular}{|c|c|c|c|}
\hline & & 2010 & 2020 \\
\hline \multirow{3}{*}{ Green Space Rate (\%) } & Central City Planning Area & 45 & 48 \\
\hline & Central City Built Area & 35 & 36 \\
\hline & Old City & 28 & 31 \\
\hline \multirow{3}{*}{ Green Coverage rate $(\%)$} & Central City Planning Area & 45 & 50 \\
\hline & Central City Built Area & 39 & 40 \\
\hline & Old City & 30 & 31 \\
\hline \multirow{2}{*}{ Green Space Per Capita $\left(\mathrm{m}^{2}\right)$} & Central City Planning Area & 50 & 50 \\
\hline & Old City & 15 & 21 \\
\hline \multirow{3}{*}{ Park Per Capita $\left(\mathrm{m}^{2}\right)$} & Central City Planning Area & 15 & 16 \\
\hline & Central City Built Area & 6 & 7 \\
\hline & Old City & 6 & 8 \\
\hline
\end{tabular}

Table 2. Green space in the Central City of Fuzhou by 2020.

\begin{tabular}{ll}
\hline the Central City of Fuzhou & data \\
\hline Green space rate & $42 \%$ \\
Green cover rate & $48 \%$ \\
Park per capita & $16.5 \mathrm{~m}^{2}$ \\
\hline
\end{tabular}

Source: Fuzhou City Planning and Design Institute. 


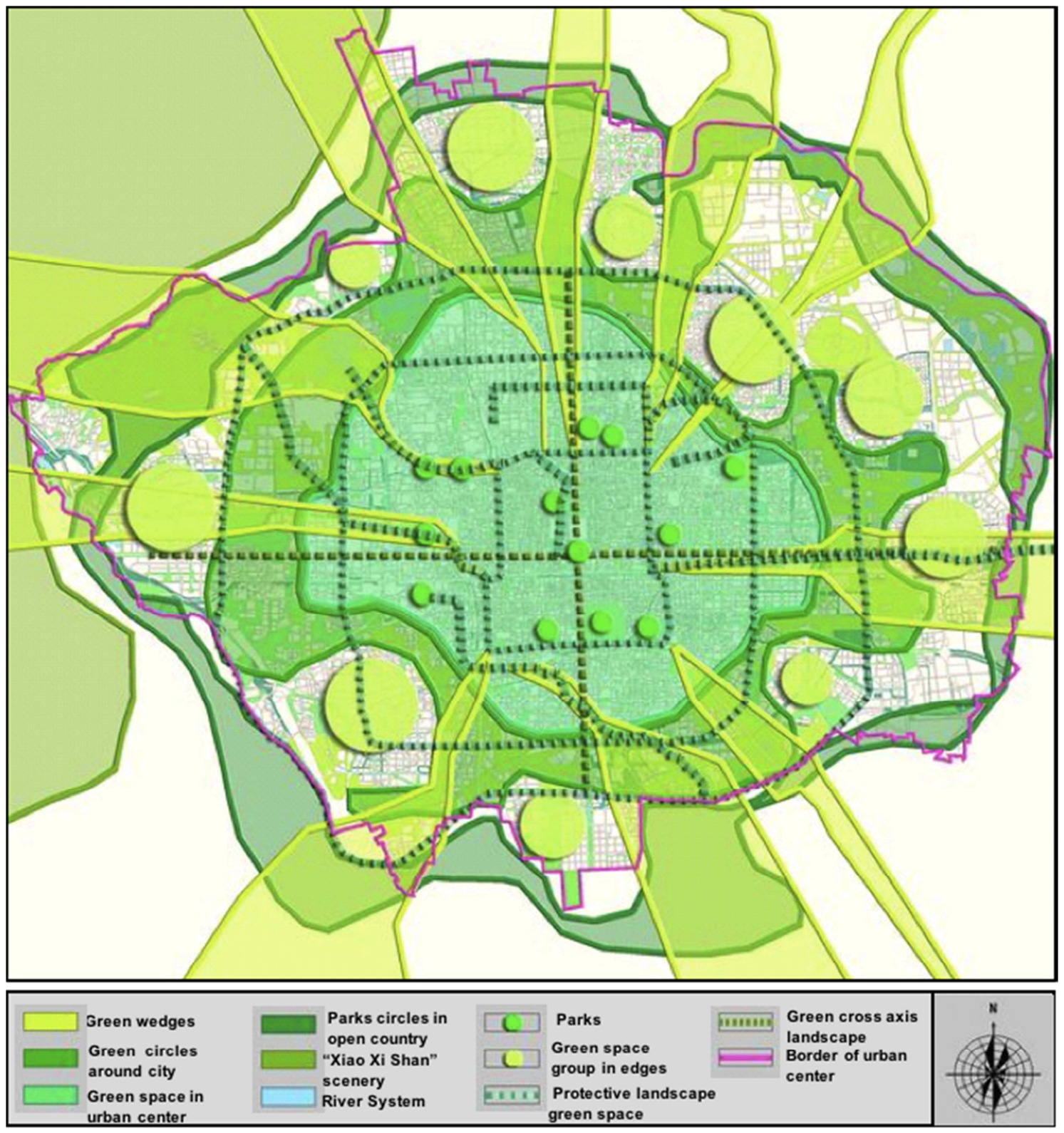

Figure 2. Green space structure in study area.

Under the provision of Beijing Urban Master Plan (20162035), the multifunctional green way in the Central City of Beijing should be built and its length would be increased from $311 \mathrm{~km}$ to $400 \mathrm{~km}$ in 2020 and to $750 \mathrm{~km}$ by the year of 2035 . This Master Plan will promote resilience, sustainability, attractiveness and livability of the Central City of Beijing by offering more green space to residents and visitors. Another thing worth mentioning is that the green coverage rate in central Dongcheng and Xicheng districts with higher population density is expected to be 33 percent and 31 percent respectively in 2020 according to Beijing Gardening and Greening Bureau while there is much legacy of history.

\subsection{Weakness of Current Green Space in the Central City of Beijing}

The green space system in the Central City of Beijing has been developed well in many aspects but it neglected climate change impacts on urban environment. Taking into account the trend of the climate change in recent years, it is needed to be more prepared by planning a green space system which can help the city to become cooler and moister in case of the Central City having nearly no ventilate potential especially in the core city which covers $92.5 \mathrm{~km}^{2}$. The poor wind condition contributes to the adverse impact of urban-heat-island in this region. Due to the vision of Urban Central Regulatory Detailed Planning of Beijing, the Central City of Beijing is divided into 33 blocks for the convenience of management. By calculating the green space rate of block01 block16, the conclusion could be drawn that the distribution of green space is uneven which contribute to the urban- heat- island in Beijing urban center (figure 3). 


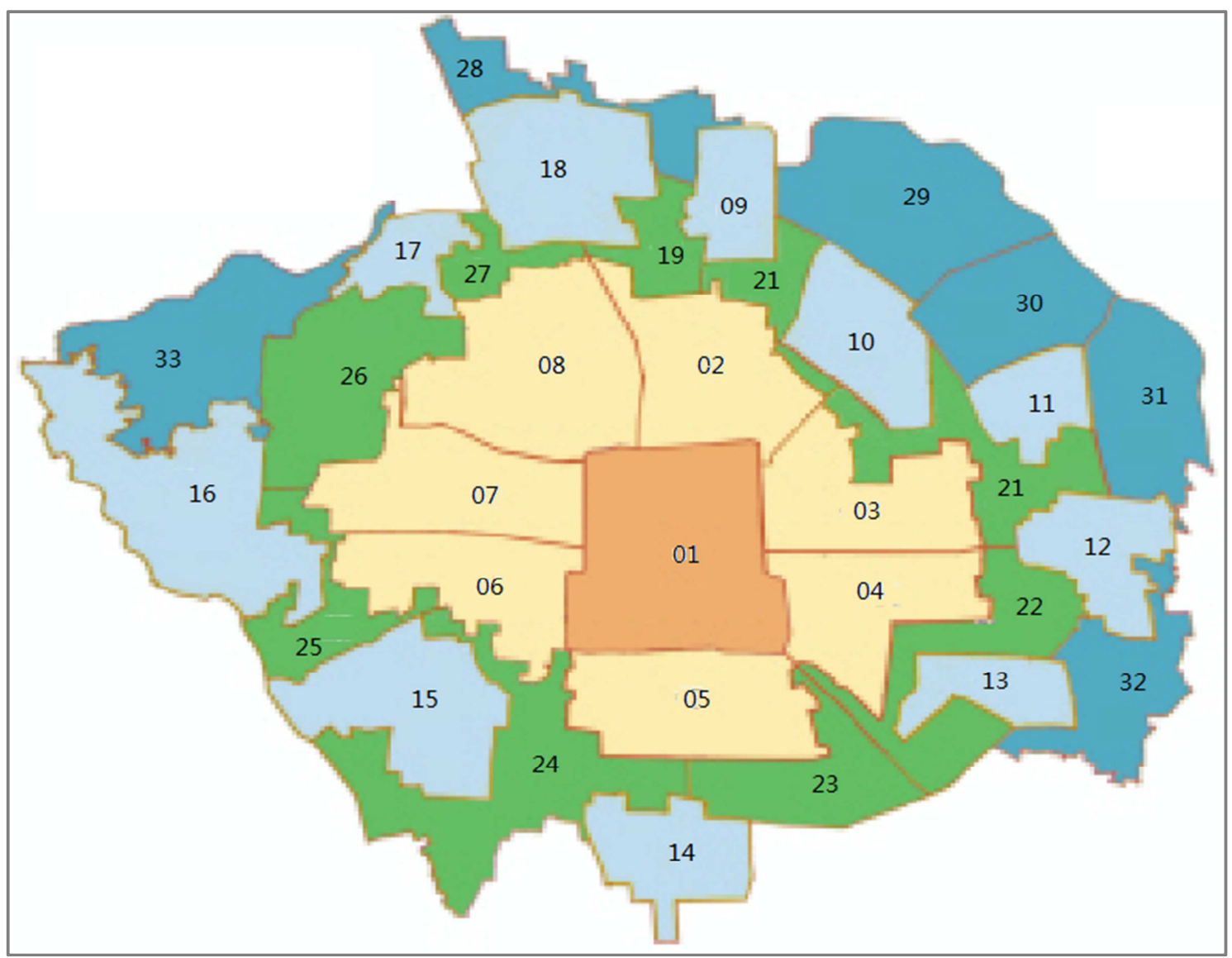

a

0.14

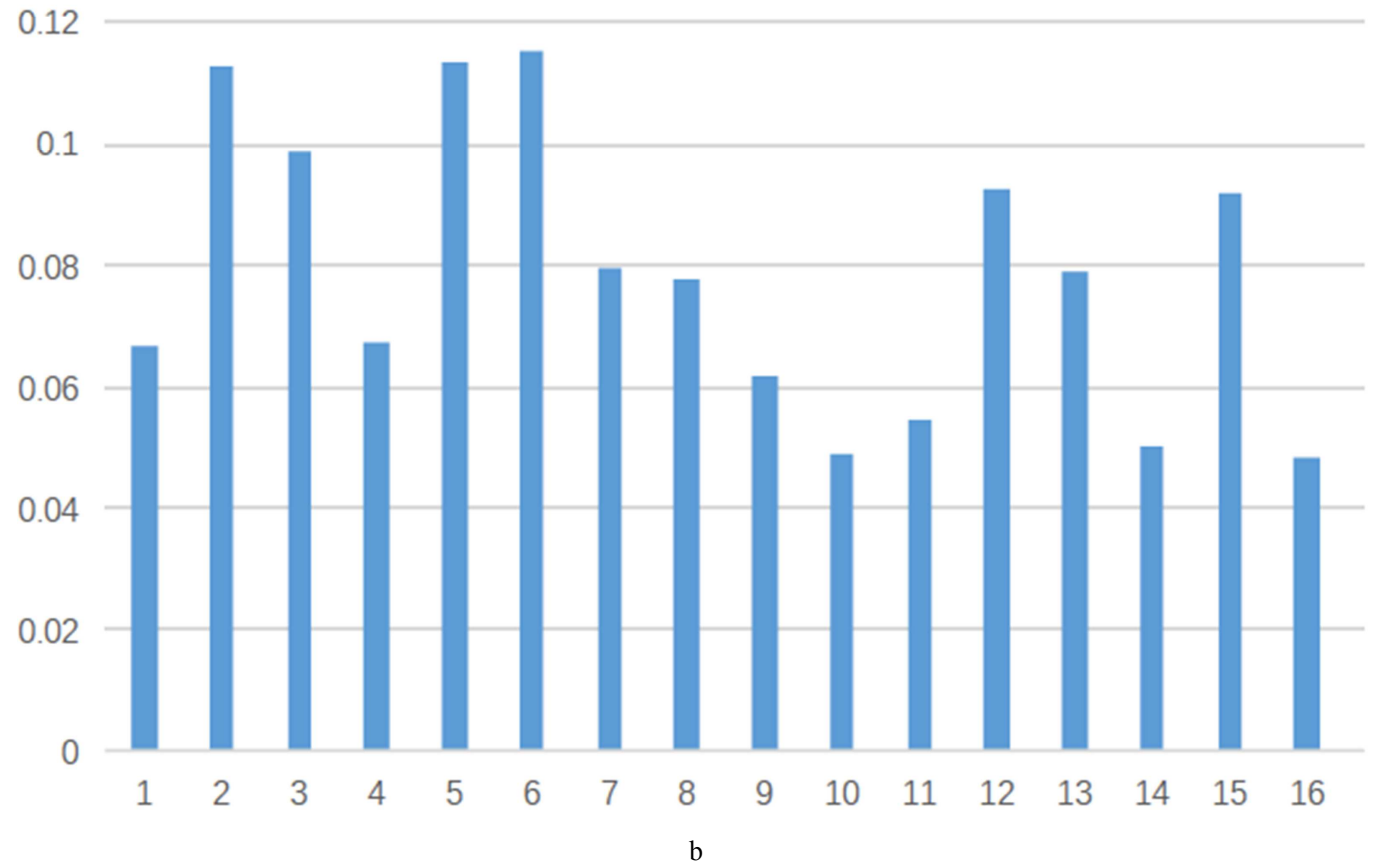

Figure 3. Green space rate in block 01 16.

It indicates that the local government placed more stress on green space structure and to some extent has ignored the climate feature in green space system planning and constructing. 


\section{The Way Forward of Planning Green Space in the Central City of Beijing}

\subsection{From the Perspective of Physical-Geography: Planning Green Space with Key Objective of Constructing "Green-Sponge-City"}

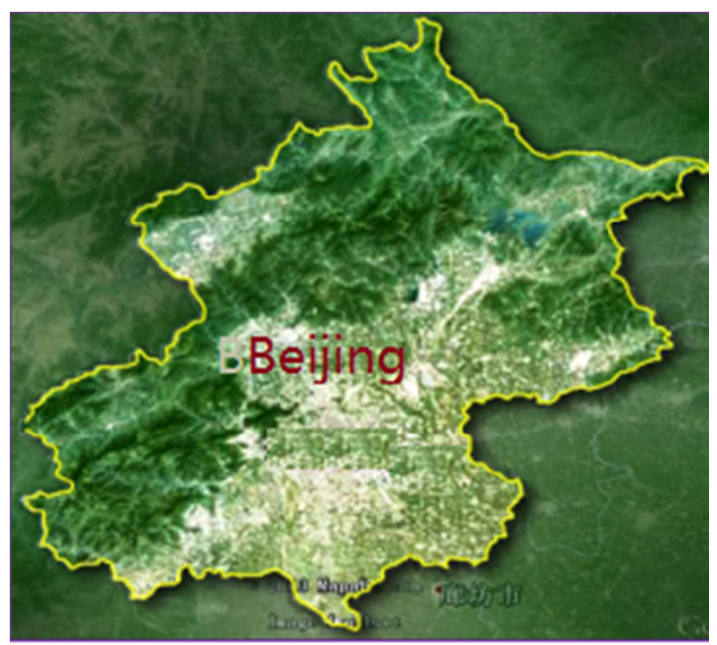

Figure 4. Beijing urban image map.

The physical geography of Beijing shows that the altitude of the north-west is much higher than south-east and the Central City of Beijing just located in the "Beijing Plain" (figure 4). Previous studies have shown that, summer has become longer and the weather has become drier due to low rainfall in Beijing in the $21^{\text {st }}$ century. The mean daily temperature in urban areas is 4.6 degree Celsius higher than that of in the suburbs. The thermal-load intensity in Beijing has increased at a rate of $0.031{ }^{\circ} \mathrm{C}$ per year [13]. Furthermore, as an impact of global climate change and rapid urbanization, the average annual temperature of Beijing from 1961 to 2010 was increased by $1.36^{\circ} \mathrm{C}$, the spatial variation of temperature was more noticeable in the southeastern and the central urban areas [14]. There is scientific data from Beijing Municipal Meterological Bureau demonstrates that the land surface temperature of the plain area including the Central City of Beijing is much higher than that of the mountains. The task ahead of urban planners is how to respond to the climate change tendency of "warmer" and "drier" by planning a resilient city for coping with climate change and environmental risks. It should be noticed that there is very few consideration on green space planning into regulating the climate in the urban center. In particular, citizens need a live-able city like green sponge instead of reinforced concrete. In 2014, China began to implement a sponge-city construction program in order to address the environmental threats to its urban centers. The Sponge City concept aims to improve effective control of urban peak runoff, and to temporarily store, recycle and purify storm water; and to integrate natural water-bodies and encourage multi-functional objectives within drainage system [15]. This drainage system would be brought into the green space system including parks and greenways to improve the status of green space in the Central City of Beijing (figure 5). In the long run, it will mitigate the drier climate and improve the harmonious of the human and nature. This setup would provide additional artificial water bodies and green spaces to deliver a higher amenity value in future.

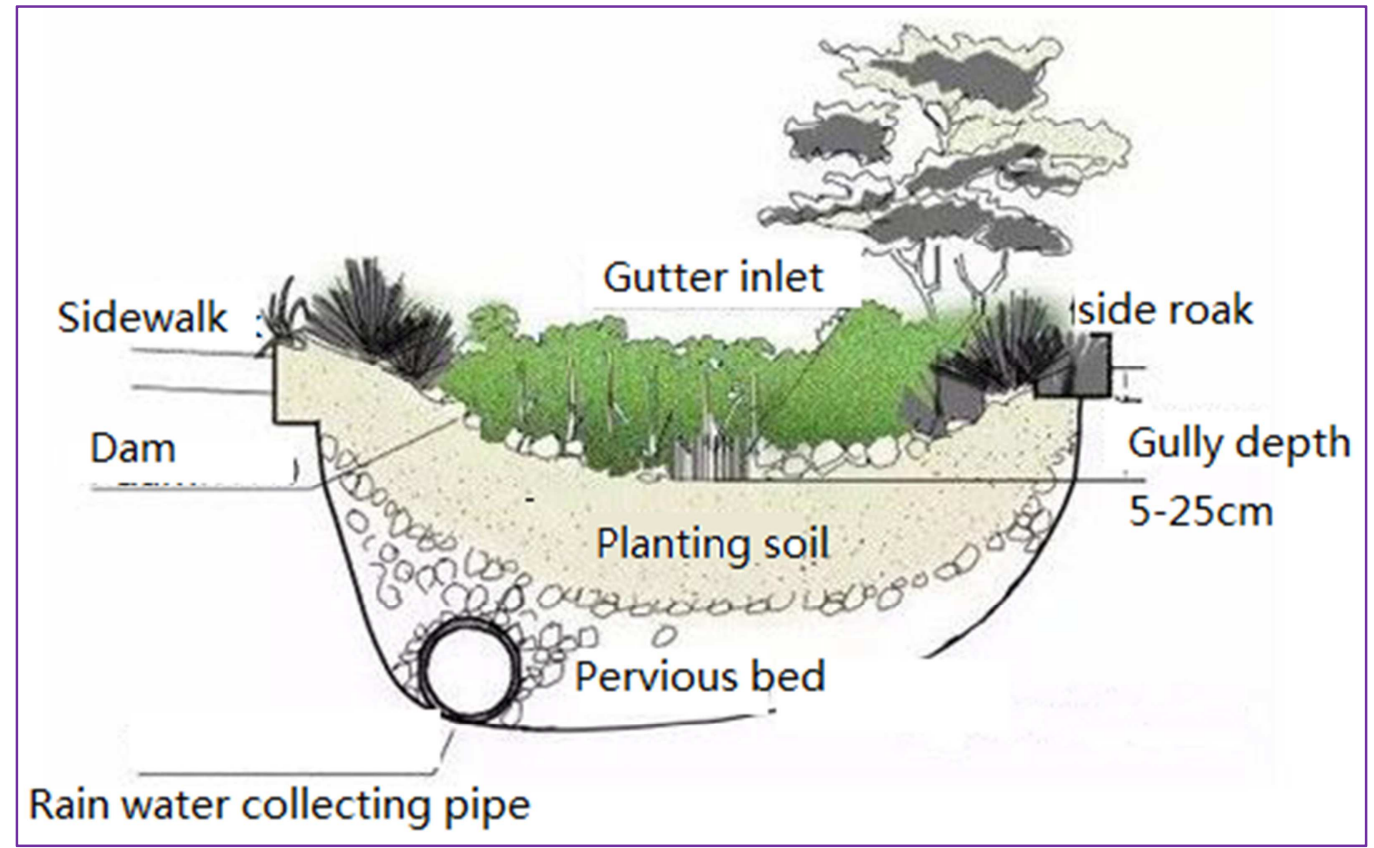

Figure 5. Conceptual picture of "sponge city".

https://imgsa.baidu.com/timg?image \&quality=80\&size $=$ b9999_10000\&sec $=1535370959031 \& d i=81 \mathrm{fb} 2 \mathrm{fea} 06 \mathrm{db} 625 \mathrm{~d} 08 \mathrm{f} 0 \mathrm{c} 35 \mathrm{f} 32 \mathrm{f0c} 2 \mathrm{ee} \& \mathrm{imgtype}=0 \& \mathrm{src}=\mathrm{http}$ $\% 3 \mathrm{~A} \% 2 \mathrm{~F} \% 2$ Fwww.fang33.com\%2Fupload\%2Fimage $\% 2$ F20170407\%2F1491555724755_z.jpg 
Considering the feature of physical geography of Beijing, green sponge in the Central City of Beijing is taking more attention in recent years than before. Local government and citizen would support new regulations and forward-thinking ideas that enhance their well-being as well as cater to climate change mitigation plan.

\subsection{From the Perspective of Socio-economic Development: Planning Green Space with the Key Concept of Constructing "Low-Carbon City"}

As China started to promote low-carbon development, research on low-carbon city has begun to thrive in recent years. The implementation of low-carbon city initially aims to reduce the emission of green-house gases. Beijing as the capital and the national historical city of China has drawn much attention to this topic from the perspective of sustainable development of smart green cities. It is well recognized that rapid expansion and sprawl of Beijing has led to some large-city-illnesses which has drawn the attention of the government and the understanding of the urgency of curing this "illness". It also should be noted that rapid urbanization has led to the high density of population in Beijing urban center (especially in Dongcheng \& Xicheng, where the population density goes up to 23953 people per $\mathrm{km}^{2}$ that is nearly 100 times of that rural and ecological areas of Beijing). Beijing has a carbon emission per capita of $8.2 \mathrm{t} /$ person per year which contributes much to the urbanheat-island in the crowded urban center. Although the Beijing People Government made ample effort to control the expansion of urban area by the "non-capital-function", the total area of the Central City of Beijing is increasing vastly and will reach to $1378 \mathrm{~km}^{2}$ (including Haidian mountain) by the year of 2020. However, the population of the Central City of Beijing will decrease from 12.80 million to 10.80 according to the Beijing Urban Master Plan. To facilitate the construction of low carbon city and eco-city in China's New Era, the suggestions for the green space planning in the Central City of Beijing are as below:

(1) ventilate corridor

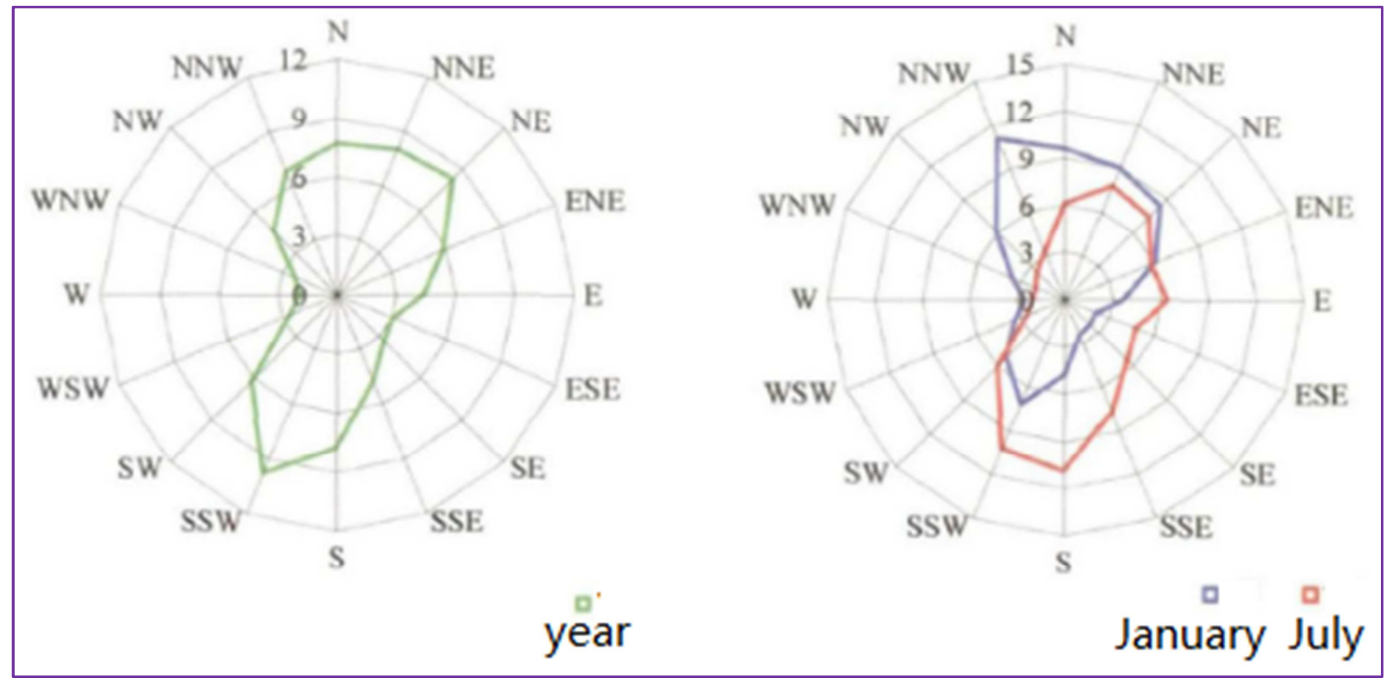

Figure 6. Beijing observatory wind direction roses from 1981 to 2015. Left: annual, right: January and July unit: \% source: Beijing Municipal Meterological Bureau.

The ventilation channel planning scheme is based on the digital analysis of meteorological conditions, urban ecosystem, urban heat island mitigation and the comprehensive consideration of urban energy saving [16]. Previous studies indicate that the wind velocity of Beijing center has decreased $20 \%$ during the past 35 years which contribute much to the thermal load there. According to the Beijing observatory wind direction roses (figure 6), the ventilation channel from north to south is the best course for air circulation. Knowing that urban green open space is the main part of the ventilation channel which help to mitigate the urban-heat-island especially in the urban center. Green space system such as parks, green way in the Central City of Beijing should join together with the urban streets, rivers to facilitate the ventilation process and improve the air condition in mitigating the climate change.

\section{(2) City-Fifth Façade}

With the development of urban landscape design and the calling for the construction of low carbon city in recent years, the City-Fifth Façade (building roofs) attracts the attention of planners. The green plants suited to the climate of Beijing such as Salix babylonica, Buxus sinic will help to cool down the building and clean the air. Green plants with carbon sequestration such as locust tree (Sophora japonica) would be one kind of the best plants of greening in the roof garden.

\section{Summary}

China is clearly aware of the challenges introduced by climate change while advancing its modernization and urbanization. It has become the main world trend that all 
countries join hands to respond to climate change and promote green low-carbon cities [17]. The first objective of Paris Agreement is to go clearly below 2 Degree Celsius for adaptation and mitigation of climate change. China announced its enhanced actions and measures on climate change in a document that was submitted to the Secretariat of United Nations Framework Convention on Climate Change in June, 2015. Furthermore, Chinese President Xi Jinping pledged to jointly push for the implementation of the Paris Agreement on climate change in a joint statement in July, 2017. Another issue worth mentioning is that the National Development and Reform Commission issued the Notification of Climate Adaptation Urban Construction in Oct. 2017. It implies that China's urban green space planning entered a new phase for the sustainable development in New Era. It should be delightful that Beijing People's Government pays increasing attention to these problems to reach above aims. In July 2017, Beijing Gardening and Greening Bureau issued the Landscape Greening in Response to Climate Change of the "thirteenth-five-year" Plan. Another issue worth mentioning is that the Beijing People Government issued "the notice of constructing sponge city of Beijing" in March, 2018 to give impetus to city construction and development. During the past 5 years, there are 40.22 million $\mathrm{m}^{2}$ leisure parks being built in Beijing City with the green coverage rate increasing up to $48.2 \%$ from $46.2 \%$ and green space per capita changing from $15.5 \mathrm{~m}^{2}$ to $16.2 \mathrm{~m}^{2}$ [18]. The local government has decided to convert the abandoned plots of land and parcels with demolished buildings in downtown Beijing into green space with grass, shrubs and trees with the goal of beautifying downtown areas and providing more comfortable places for dwellers there [19]. There is no doubt that these actions would enhance the ability of the city to cater to the climate change. However, further action is needed to be taken to be resilience to climate change with particular focus on green space planning. Some of future actions in Beijing that support urban green space planning in response to climate change mitigation and adaptation were mentioned in Beijing Urban Master Plan (2016-2035). A modern international Beijing City with distinct characteristics will come into being until 2020. That is "Modern International City". Beijing has a long term plan of green sustainable ecosystem that is connected with green wedges, parks and green corridors called "Eco-City" [20]. Most important of all, the construction of Beijing City Sub Center and Beijing as the host city of the 2022 winter Olympics are both calling on the climatic adaptability of the green space system. Furthermore, the harmony development of the Beijing-Tianjin-Hebei port group needs the green space system of Beijing to adapt to the climate change in New Era of China. The urban climatic strategy on the greening of China and that of Beijing are reviewed. If great emphasis on green space system and other sustainable infrastructure are placed, better growth and better development and a better climate in Beijing are within reach. Only in this way, Premier Xi's "blue sky, green mountains and clean water" would be realized in future [21].

\section{References}

[1] Zhaowu Yu, Xieying Guo, Gertrud Jørgensen, Henrik Vejre, How can urban green spaces be planned for climate adaptation in subtropical cities?, In Ecological Indicators, Volume 82, 2017, Pages 152-162, ISSN 1470-160X.

[2] Xiaodong He, Shuanghe Shen, Shiguang Miao, Jingjing Dou, Yizhou Zhang, Quantitative detection of urban climate resources and the establishment of an urban climate map (UCMap) system in Beijing, In Building and Environment, Volume 92, 2015, Pages 668-678.

[3] X. X. Zhang, P. F. Wu, B. Chen, Relationship between vegetation greenness and urban heat island effect in Beijing City of China, In Procedia Environmental Sciences, Volume 2, 2010, Pages 1438-1450, ISSN 1878-0296.

[4] Kazemi, F, Beecham, S, Razzaghmanesh, M, Conference, tI \& December, WotBEiDCA- 2012, 'Introducing green infrastructure into the built environment of Adelaide', ICBEDC.

[5] Wolch, J. R., et al. (2014). "Urban green space, public health, and environmental justice: The challenge of making cities 'just green enough'." Landscape and Urban Planning 125: 234-244.

[6] Xiaodong He, Shuanghe Shen, Shiguang Miao, Jingjing Dou, Yizhou Zhang, Quantitative detection of urban climate resources and the establishment of an urban climate map (UCMap) system in Beijing, In Building and Environment, Volume 92, 2015, Pages 668-678.

[7] Feng Li, Paul C. Sutton, Sharolyn J. Anderson \& Hamideh Nouri (2017) Planning green space in Adelaide city: enlightenment from green space system planning of Fuzhoucity (2015-2020), Australian Planner, 54: 2, 126-133, DOI: $10.1080 / 07293682.2017 .1345962$, http://dx.doi.org/10.1080/07293682.2017.1345962

[8] https://www.beijingtrip.com/facts/climate.htm

[9] Tang Yan; Chen Kai; Li Caige;. Governance of Urban Green Open Space for Responding to Climate Change [J]. China City Planning Review, 2017.03.

[10] Xiaodong He, Shuanghe Shen, Shiguang Miao, Jingjing Dou, Yizhou Zhang, Quantitative detection of urban climate resources and the establishment of an urban climate map (UCMap) system in Beijing, Building and Environment, Volume 92, 2015, Pages 668-678, ISSN 0360-1323, https://doi.org/10.1016/j.buildenv.2015.05.044.

[11] Yazhou Zhang, Yulin Zhan, Tao Yu, Xinyu Ren, Urban green effects on land surface temperature caused by surface characteristics: A case study of summer Beijing metropolitan region, Infrared Physics \& Technology, Volume 86, 2017, Pages 35-43, ISSN 1350-4495,

https://doi.org/10.1016/j.infrared.2017.08.008.

[12] Mahua Mukherjee, Kaoru Takara, Urban green space as a countermeasure to increasing urban risk and the UGS-3CC resilience framework, International Journal of Disaster Risk Reduction, 2018, ISSN 2212-4209, https://doi.org/10.1016/j.ijdrr.2018.01.027.

[13] Ranhao Sun, Liding Chen, Effects of green space dynamics on urban heat islands: Mitigation and diversification, Ecosystem Services, Volume 23, 2017, Pages 38-46, ISSN 2212-0416, https://doi.org/10.1016/j.ecoser.2016.11.011. 
[14] Countermeasures of Climate Change Adaptation in Beijing. Shi C and Pang S. Report on Development of Public Service in Beijing (2013-2014). Beijing: Social Sciences Academic Press, pp. 304-315.

[15] Faith Ka Shun Chan, James A. Griffiths, David Higgitt, Shuyang Xu, Fangfang Zhu, Yu-Ting Tang, Yuyao Xu, Colin R. Thorne, "Sponge City" in China-A breakthrough of planning and flood risk management in the urban context, Land Use Policy, 2018, ISSN 0264-8377, https://doi.org/10.1016/j.landusepol.2018.03.005.

[16] $\mathrm{Na} \mathrm{Su}$, Dian Zhou, Xiaotao Jiang, Study on the Application of Ventilation Corridor Planning in Urban New Area --A Case Study of Xixian New Area, Procedia Engineering, Volume 169, 2016, Pages 340-349, ISSN 1877-7058, https://doi.org/10.1016/j.proeng.2016.10.042.

[17] http://english.gov.cn/archive/white_paper/2014/09/09/content 281474986284685.htm
[18] http://english.forestry.gov.cn/index.php?option=com content $\&$ view=category\&layout $=$ blog\&id $=16 \&$ Itemid $=159 \&$ limitstar $\mathrm{t}=5$

[19] http://english.qianlong.com/2018/0126/2355762.shtml

[20] Feng Li, Rusong Wang, Juergen Paulussen, Xusheng Liu, Comprehensive concept planning of urban greening based on ecological principles: a case study in Beijing, China,

Landscape and Urban Planning, Volume 72, Issue 4, 2005 , Pages 325-336, ISSN 0169-2046,

https://doi.org/10.1016/j.landurbplan.2004.04.002.

[21] Edward Ng, Chao Ren, China's adaptation to climate \& urban climatic changes: A critical review, Urban Climate, Volume 23, 2018, Pages 352-372, ISSN 2212-0955, https://doi.org/10.1016/j.uclim.2017.07.006. 